\title{
Bio-monitoring of Environmental Toxicants using West African Dwarf Goats at Amawzari Mbano, Imo State, Nigeria
}

\author{
Ogbonna P. C. ${ }^{1, *}$, Dikeogu, E. C. ${ }^{2}$, Nwankwo, O. U. ${ }^{3}$, Kanu, K. C. ${ }^{4}$ and \\ Osuagwu E. C. . $^{2}$ \\ ${ }^{1,2,3,4,5}$ Department of Environmental Management and Toxicology, Michael Okpara University of Agriculture, \\ Umudike, Abia State, Nigeria \\ Corresponding Author: *ogbonna_princewill@yahoo.com
}

https://doi.org/10.36263/nijest.2021.01.0279

\begin{abstract}
Several health risks have been linked to exposure to environmental toxicants in food consume by man. This study aimed to determine the level of environmental toxicants in goats tended by rural farmers. Fur and blood samples were carefully collected from sixteen (16) goats in open range husbandry (ex situ) at four sites in Amawzari, Imo State, Nigeria. The samples were digested and analyzed separately to determine the concentrations of some environmental toxicants (heavy metals). The concentrations of $\mathrm{Pb}, \mathrm{Cr}, \mathrm{Cd}$ and $\mathrm{Ni}$ in blood were 0.01 to 0.05, 0.01 to 0.07, 0.00 to 0.01 and 0.05 to $0.12 \mathrm{mg} / \mathrm{kg}$, while their concentration in fur were 0.02 to $0.03,0.001$ to 0.006 , 0.00 to 0.00 , and 0.04 to $0.05 \mathrm{mg} / \mathrm{kg}$, respectively. Pearson correlation analysis show very strong positive relationship between $\mathrm{Pb}$ in blood and $\mathrm{Pb}$ in fur $(r=0.855, p<0.01)$ and $\mathrm{Ni}$ in blood and Ni in fur $(r=0.811, p<0.01)$. The order of abundance of the four heavy metals tested in goat fur and blood is $\mathrm{Ni}>\mathrm{Cr}>\mathrm{Pb}>\mathrm{Cd}$. Based on our findings, the concentrations of heavy metals in blood were higher than its corresponding values in fur. Thus, consumption of meat processed from these metal-contaminated goats and utilization of their blood to manufacture blood meal for pigs and poultry birds will result to bio-magnification of heavy metals in man and animals. Therefore, we recommend that rural farmers should be enlightened on health challenges associated with in situ form of animal husbandry.
\end{abstract}

Keywords: Environmental toxicants, Blood, fur, West African dwarf goats, Amawzari

\subsection{Introduction}

The West African Dwarf (WAD) goat is the commonest and most important indigenous goat breed in the 18 countries of West and Central Africa (ILCA, 1987) but Nigeria hosts the largest WAD goat population with approximately 11 million in the humid zone of Eastern Nigeria (Chiejina and Behnke, 2011). It is estimated that at least $90 \%$ of these animals are owned by small-holder rural goat keepers, for whom goats represent an important asset (Jabbar, 1998). Goats provide their owners with a broad range of products and socio-economic services such as cash income (meat), security (milk), gifts (skin), and manure for crops (Chiejina and Behnke, 2011). Goats account for about $30 \%$ of Africa's ruminant livestock and produce about $17 \%$ and $12 \%$ of its meat and milk, respectively (Wilson, 2011). Goat is an excellent source of meat called chevron (that is meat from adult goat) which is composed mainly of proteins, fat and some important essential elements and is necessary for growth and maintenance of good health. The protein in goat meat is higher than most of other meats and the fat content is lower than beef or pork (FAO/WHO, 1985).

Goats not only play a vital role in ensuring food security of a household (often being the only asset possessed by a poor household), but when needed and in time of trouble (e.g. crop failure or family illness, school fees), goats may be sold to provide an important source of cash (Peacock, 2005). Any intervention aiming to improve goat productivity will therefore have an immediate socio-economic impact on rural communities, especially the poorest of these for whom goats represent the only livestock they can afford to raise (Chiejina and Behnke, 2011). For about a decade now, factors such as increase in human population, construction of more buildings to ameliorate the challenges of 
accommodation, decline in soil fertility among others have resulted to serious short fallow period in South east Nigeria. The cut-and-carry fodder/foliage, which are important ingredients in the husbandry of goats in rural areas is taking tolls on the rural farmers because they spend quantum of time walking distances to collect forage or grasses for their goats that are domesticated in their various homes. This invariably affects other activities embarked by the farmers such as farming, selling of farm products at the market, fetching of water from streams, collection of fuel wood, preparation of food and time spent with their families. Consequently, most livestock farmers resulted to moving their goats to various locations where there are grasses and forage plants. This, however, may expose the domestic animals to the deposition of contaminants on their furs.

The environment is exposed to continuous contamination due to human activities such as industrial production, agricultural processes, mineral exploitation, food processing, commercial, social, and domestic activities (Ogbonna et al., 2018). These anthropogenic activities release potential toxic element such as heavy metals into the aquatic and terrestrial ecosystems. For instance, waste water runoff from industries/factories enters fallow/pasture lands as a result of lack of proper drainage system. Indiscriminate discharge of untreated industrial waste water enhances the concentrations of heavy metals in the environment. Particulate matter such as dust and vehicular exhaust smoke contains relative amount of heavy metals that might settle on grasses and fodder plants consume by livestock, thus, contaminating and bio-accumulating in the organs, tissues, and hair/furs of the livestock. Hairs contain sulfhydryl group that can bind toxic element for a long period of time resulting to forgetfulness, nerve damage, lung embolism and bronchitis due to manganese poisoning (Santamaria, 2008). Zinc, lead, aluminum and copper poisoning are implicated for gastrointestinal disorder, ataxia, vomiting, convulsion and paralysis (McCluggage, 1991).

Owing to close association and common environment shared with humans, domestic goats are exposed to similar pollutants and have been suggested as sentinels for biohazards from pollutants (Swarup et al., 2000; Berny et al., 1995). Since furs of domestic goats may accumulate trace elements or heavy metals for a longer period of time and are known to be metabolically inert, it (furs) will serve as an important indicator to determining the level of environmental exposure of goats to heavy metal. Hair tissues analysis has been found to be an excellent tool for monitoring general health and nutritional status for both animals and human (Manson and Zlotkin, 1985; Bhattacharya et al., 2004).

Literature search showed that there is paucity of research carried out on the concentration of heavy metals in goats over the world. These studies are: heavy metals in selected tissues and organs of slaughtered goats from Akinyele Central Abattoir, Ibadan, Nigeria (Oladipo and Okareh, 2015), heavy metals and trace elements in the livers and kidneys of slaughtered cattle, sheep and goats from West of Iran (Bazargani-Gilani et al., 2016), survey of trace elements and some heavy metals in goats in Zaria and its environs, Kaduna State (Omoniwa et al., 2017). Furthermore, assessment of heavy metals in the blood and some selected entrails of cows, goat and pigs slaughtered at Wurukun abattoir, Makurdi, Nigeria (Ubwa et al., 2017), concentration of some heavy metals in the hair, kidney and liver of cattle and goats in the oil and non-oil producing areas of Ondo State, Nigeria (Egigba et al., 2018), assessment of heavy metals contents in goat and sheep organs from Ashaka Cements, Gombe State, Nigeria (Chadi and Abdulhameed, 2018) but none of these studies determined the concentrations of potential toxic element in fur and blood in WAD goats. This study, therefore, is aimed to determine the concentrations of heavy metals in fur and blood of WAD goats at open range husbandry (ex situ) in Amawzari Mbano in Imo State, Nigeria. The results of this study will provide baseline information on the level of heavy metals contamination in the WAD goats and possible health hazards associated with consumption of such meat in the area.

\subsection{Materials and Methods}

\subsection{Study area}

The study was carried out at Amawzari in Isiala Mbano Local Government Area of Imo State, Nigeria (Figures 1 and 2). The headquarters of Isiala Mbano LGA is Umuelemai, and it lies between latitude $5.71^{\circ} \mathrm{N}$ and longitude $7.18^{\circ} \mathrm{E}$ on the equator. It is located in the tropical rainforest zone of Nigeria (Keay, 1959). According to the National Population Commission (NPC, 2006) of Nigeria, Isiala Mbano had a population of 198,736. 


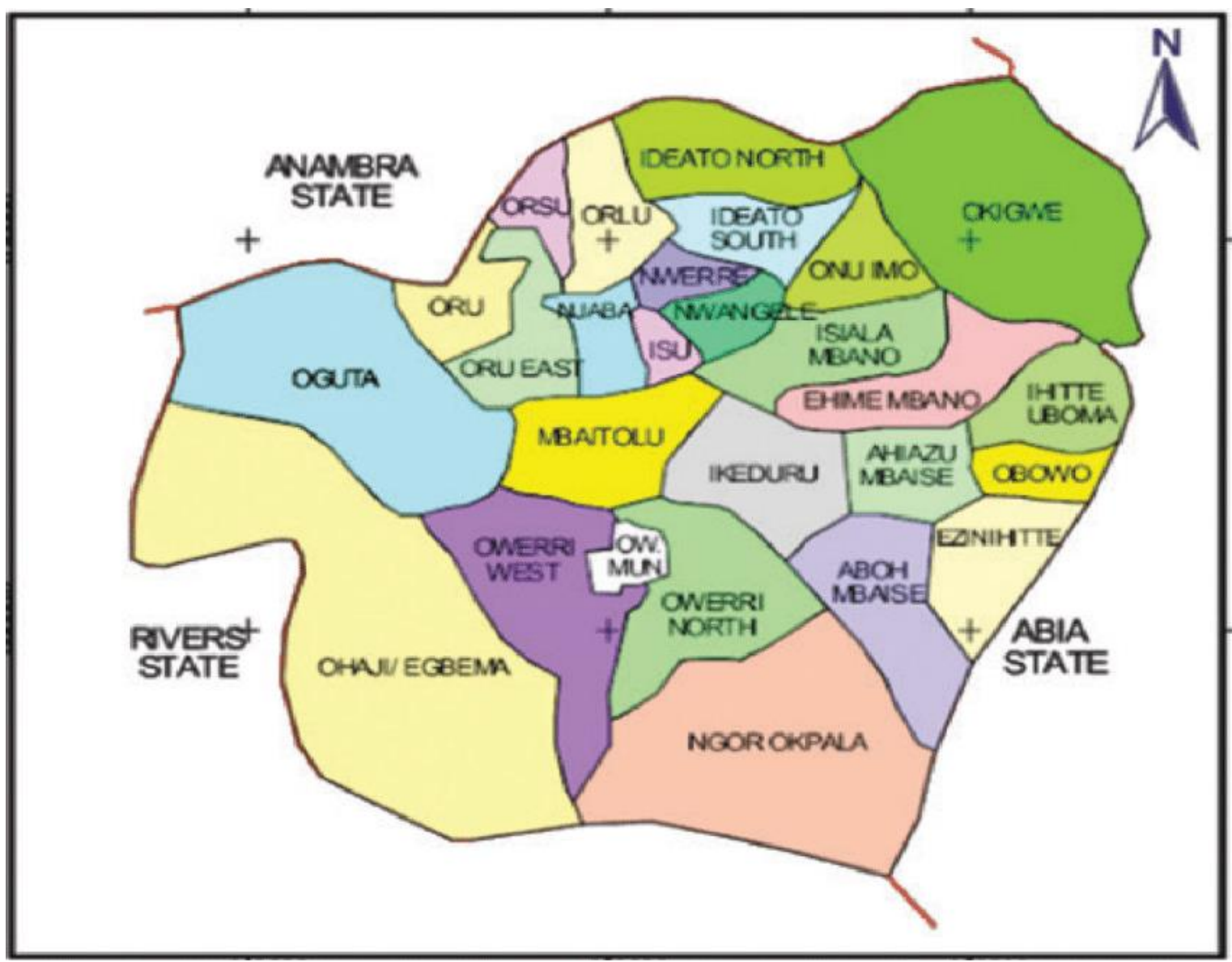

Figure 1: Map of Imo State showing Isiala Mbano LGA

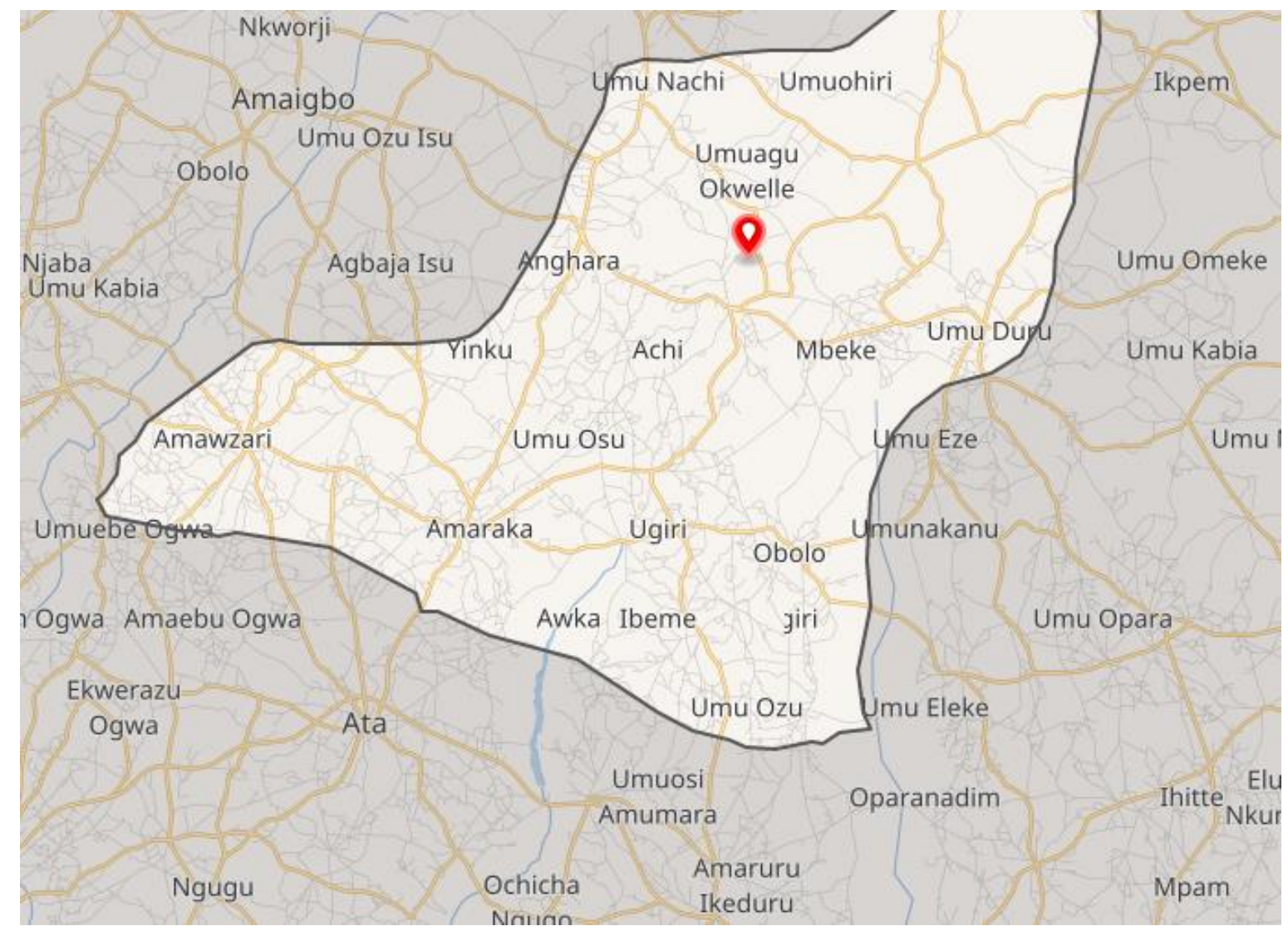

Figure 2: Map of Isiala Mbano showing Amawzari

It is bounded on the north by Onuimo Local Government Area and some parts of Nwangele Local Government Area, on the east by Isu and some parts of Nwangele Local Government Areas, on the 
south by Ehime Mbano, Ahiazu Mbaise and Ikeduru Local Government Areas, while it has boundary on the west with Ihite Uboma and Obowo Local Government areas. It experience two distinct seasons viz the wet and dry seasons. The dry season begins in November and ends in March while the wet season commence in April and ends in October with peak in July and September. Though, there may be relative break in August, the average annual rainfall is between $1800 \mathrm{~mm}$ and $2280 \mathrm{~mm}$ (Warris, 2013). Over the course of the year, the temperature typically varies from $66^{\circ} \mathrm{F}$ to $87^{\circ} \mathrm{F}$ and is rarely below $59^{\circ} \mathrm{F}$ or above $90^{\circ} \mathrm{F}$ (https://weatherspark.com/y/54991/Average-Weather-in-UmuelemaiNigeria-Year-Round). The local populace practice subsistence farming that include rearing of domestic livestock especially goats, cultivation of crops such as cassava, maize, yam, cocoyam, plantain, fluted pumpkin, okra, pepper, oil palm trees and fruit trees like Dacryodes edulis, Treculia africana, Carica papaya among others (Field visit).

\subsection{Sample collection}

Prior to sample collection, reconnaissance survey was carried out to determine the various locations where the farmers tied their goats every morning for preceding three (3) years for foraging. In Amauzari, domestic goats are usually brought out and tied to pole-like stalks to feed in the morning and are taken home in the evenings.

\subsection{Collection, digestion and analysis of blood sample}

Four (4) locations were used for the study and four goats were selected from each location for sample collection. Fresh blood samples were collected separately from each goat at each location via vein puncture using sterilized syringes. The blood sample from each goat was collected in $25 \mathrm{~mL}$ clean sterilized metal-free plastic bottles with gentle handling to prevent hemolysis (Ubwa et al., 2017). The sample was placed in icebox and transported to the laboratory. In order to prevent platelet disintegration, it was kept frozen at $4^{\circ} \mathrm{C}$ in the freezer until the time for pre-treatment and analysis of heavy metals. Samples from each location was thoroughly mixed and homogenized. Sub sample was taken from each homogenized samples for digestion. The wet digestion method of FAO (1990), Licata et al. (2004) and Ubwa et al. (2017) was adopted with minor modification. About $0.5 \mathrm{~mL}$ of the blood sample from each location was predigested with $10 \mathrm{~mL} \mathrm{1:1} \mathrm{concentrated} \mathrm{HNO}_{3}$ and $\mathrm{HCLO}_{4}$ acids on a hot plate at $120^{\circ} \mathrm{C}$ until the liquor had finished undergoing oxidation. Then $5 \mathrm{~mL} \mathrm{H}_{2} \mathrm{O}_{2}$ was added and temperature was maintained at $120^{\circ} \mathrm{C}$ for an hour and 30 minutes until the liquor got completely digested and showed a clear colour. The product of the digestion was allowed to slowly evaporate to near dryness and the digests (blood) was cooled and filtered through Whatman (No. 42) filter paper into $100 \mathrm{~mL}$ volumetric flask and made up to the mark with deionized water. Thereafter, determination of the amount of each heavy metal $(\mathrm{Pb}, \mathrm{Cd}, \mathrm{Ni}$, and $\mathrm{Cr}$ ) was carried out using PerkinElmer analyst 300 Atomic Absorption Spectrophotometer (AAS). The control samples were collected from goat reared indoors (in situ i.e. that are fed and restricted within a hut).

\subsection{Collection, digestion and analysis of hair}

About $1.5 \mathrm{~g}$ hair were collected randomly and separately from different body parts (neck, tail, belly and back) of four (4) goats at each location using well cleaned stainless steel scissors and stored separately in well cleaned zip locks, labeled well and well-sealed, stored in a wooden box to avoid cross contamination from external sources and taken to the laboratory for pre-treatment and analysis. Hairs of goats from each location were bulked together and homogenized. The hair samples were washed briefly with acetone, deionized water, then again with acetone and oven dried at $105^{\circ} \mathrm{C}$ for 4 hours. Then $1 \mathrm{~g}$ of the hair was manually cut to small, homogenized pieces and treated with $10 \mathrm{ml}$ of $\mathrm{HNO}_{3}, \mathrm{HClO}_{4}$ and $\mathrm{H}_{2} \mathrm{SO}_{4}$ acid mixture in a ratio of 8:1:1, which was heated to near dryness. The product of the digestion was allowed to slowly evaporate to near dryness. At the end of complete digestion, the digest (hair) was cooled and filtered (Ubwa et al., 2017) through Whatman (No. 42) filter paper into $100 \mathrm{ml}$ volumetric flask and made up to mark with distilled water. The control samples were collected from goat reared indoors (i.e. that are fed and restricted within a hut).

\subsection{Quality assurance and quality control}

For quality assurance and control measures, high purity reagents of analytical grades were obtained from British Drug Houses (BDH) Chemicals Ltd., UK. All plastic and glass containers were cleaned by soaking in dilute $\mathrm{HNO}_{3}$, rinsed in distilled water six times, rinsed in deionized water three times, 
oven dried (but for zip locks that were air dried) and cool before use. Reagent blanks and a series of standard solutions of $0.5,1.0,2.0,5.0,10.0$ and $100 \mathrm{mg} / \mathrm{l}$ were prepared from the stock standard solution of each test heavy metal by diluting known volumes of the stock solution in $100 \mathrm{ml}$ volumetric flasks using distilled water. The elements that were determined at their various wavelengths were $\mathrm{Cr}=283.5, \mathrm{Ni}=221.6, \mathrm{Cu}=766.5, \mathrm{~Pb}=220.3, \mathrm{Zn}=213.9, \mathrm{Cd}=228.8, \mathrm{Fe}=510$ and $\mathrm{Mn}=279.5 \mathrm{~nm}$.

\subsection{Experimental design and statistical analysis}

A total of sixteen (16) goats were sampled from four (4) different locations in Amauzari (i.e. 4 from each location). The location serves as a block while the four goats from each location are the replicates. The experiment was carried out as a simple factorial in Randomized Complete Block Design (RCBD). The data generated from laboratory analysis were subjected to one-way analysis of variance (ANOVA) using Statistical Package for Social Sciences (SPSS), and means were separated with Duncan New Multiple Range Test, DNMRT (Steel and Torrie, 1980).

\subsection{Results and Discussion}

\subsection{Concentration of environmental contaminants in blood and fur}

The concentrations of environmental contaminants such as heavy metals assessed in the blood of goats are summarized in Table 1. The results indicate that highest and lowest concentrations of the metals were observed in goats at ex situ and in situ (control) sites, respectively. The concentration of $\mathrm{Pb}$ were statistically the same at Site $1(0.05 \pm 0.01 \mathrm{mg} / \mathrm{kg})$, Site $2(0.04 \pm 0.01 \mathrm{mg} / \mathrm{kg})$, Site 3 $(0.05 \pm 0.01 \mathrm{mg} / \mathrm{kg})$ and Site $4(0.04 \pm 0.01 \mathrm{mg} / \mathrm{kg})$ but the values are significantly $(p<0.05)$ higher than the control $(0.01 \pm 0.00 \mathrm{mg} / \mathrm{kg})$. The high concentration of $\mathrm{Pb}$ in goat blood at Sites $1,2,3$ and 4 may be attributed to high deposition of contaminants $(\mathrm{Pb}, \mathrm{Cd}, \mathrm{Cr}$ and $\mathrm{Ni}$ ) on grasses and fodders at these locations and subsequent consumption, digestion and assimilation of metals into their blood stream. Studies have shown that grasses, fodders and roughages grown in agricultural sites, industrial areas, and sewer water irrigation fields contain heavy metals (Mora et al., 2000; Dietz et al., 2001; Rozso et al., 2003). The place of animal rearing, dietary habits and exposure time are important factors in heavy metal contamination of livestock (Sabir et al., 2003). Inhalation is one of the major entries of heavy metals (Järup, 2003), thus, inhalation is another route of entry of metals into the body of goats in ex situ.

The values of $\mathrm{Pb}$ in the blood increased from 0.01 to $0.05 \mathrm{mg} / \mathrm{kg}$ which is lower than $0.068 \pm 0.0227$ $\mathrm{mg} / \mathrm{l}$ in goat blood at Turkey (Yazar et al., 2006), $0.56 \mathrm{mg} / \mathrm{l}$ in goat blood at Shagamu, Ogun State (Oluokun et al., 2007), 0.259 $\pm 0.470 \mathrm{mg} / \mathrm{l}$ in goat blood at Kaduna State (Omoniwa et al., 2017), $5.0867 \pm 2.9326$ to $7.755 \pm 7.4943 \mathrm{mg} / \mathrm{kg}$ in goat blood at Zamfara State (Orisakwe et al., 2017), $0.411 \pm 0.021 \mathrm{mg} / \mathrm{kg}$ in sheep blood in China (Shen et al., 2019) and $0.31 \pm 0.03 \mathrm{mg} / \mathrm{kg}$ in human blood at China (Shen et al., 2019). Pb has no positive biological function in the growth and development of man. Lead $(\mathrm{Pb})$ is known to alter the hematological system by inhibiting the activities of several enzymes involved in heme-biosynthesis (Okiei et al., 2009). Exposure to $\mathrm{Pb}$ is considered to be detrimental and associated with behavioral abnormalities, hearing deficits, neuromuscular weakness, and impaired cognitive functions in humans and experimental animals (Flora et al., 2012; Assi et al., 2016). Acute and chronic lead poisoning contributes in vascular and cardiac damage as well as possible fatal consequences such as cardiovascular illnesses and hypertension (Navas-Acien et al., 2007).

The highest concentration of $\mathrm{Cr}$ in blood was recorded in goats at Site 1 and the value is significantly $(p<0.05)$ higher than values of $\mathrm{Cr}$ obtained in goat blood at Site $2(0.02 \pm 0.01 \mathrm{mg} / \mathrm{kg})$, site 3 $(0.02 \pm 0.01 \mathrm{mg} / \mathrm{kg})$, site $4(0.01 \pm 0.00 \mathrm{mg} / \mathrm{kg})$, and the control $(0.00 \pm 0.00 \mathrm{mg} / \mathrm{kg})$. The source of $\mathrm{Cr}$ in goat blood may be attributed consumption of fodders, grasses and water contaminated by Cr. Indeed, Imo State is an oil producing State and share boundaries with Rivers State, hence, gas flaring and other industrial activities in Rivers State may result to atmospheric deposition of metals on soil, grasses and water at the study site and subsequent uptake by the goats. The values of $\mathrm{Cr}$ in goat blood increased from 0.01 to $0.07 \mathrm{mg} / \mathrm{kg}$ which is lower than 0.009 to $0.092 \mathrm{mg} / \mathrm{l}$ (Pechova and Pavlata, 2007), $2.7683 \pm 0.5477$ to $2.9219 \pm 1.1640 \mathrm{mg} / \mathrm{kg}$ (Orisakwe et al., 2017), $0.18 \mathrm{mg} / \mathrm{l}$ (Ubwa et al., 2017), and 0.072 $\pm 0.064 \mathrm{mg} / \mathrm{l}$ (Omoniwa et al., 2017). Chromium cause ulceration and perforation of 
the nasal system (Shekhawat et al., 2015), acute tubular necrosis, vomiting, abdominal pain, kidney failure and even death (Beaumont et al., 2008). Human liver, kidney, spleen and bone have more concentration of $\mathrm{Cr}$ in comparison to other organs (NTP, 2008).

Table 1: Heavy metals on blood of domestic goat

\begin{tabular}{lcccc}
\hline Samples & $\mathrm{Pb}$ & $\mathrm{Cr}$ & $\mathrm{Cd}$ & $\mathrm{Ni}$ \\
\hline Site 1 & $0.05^{\mathrm{a}} \pm 0.01$ & $0.07^{\mathrm{a}} \pm 0.02$ & $0.00^{\mathrm{b}} \pm 0.00$ & $0.10^{\mathrm{a}} \pm 0.01$ \\
Site 2 & $0.04^{\mathrm{a}} \pm 0.01$ & $0.02^{\mathrm{b}} \pm 0.01$ & $0.00^{\mathrm{b}} \pm 0.00$ & $0.10^{\mathrm{a}} \pm 0.02$ \\
Site 3 & $0.05^{\mathrm{a}} \pm 0.01$ & $0.02^{\mathrm{bc}} \pm 0.00$ & $0.00^{\mathrm{b}} \pm 0.00$ & $0.10^{\mathrm{a}} \pm 0.01$ \\
Site 4 & $0.04^{\mathrm{a}} \pm 0.01$ & $0.01^{\mathrm{bc}} \pm 0.00$ & $0.01^{\mathrm{a}} \pm 0.00$ & $0.12^{\mathrm{a}} \pm 0.01$ \\
Control & $0.01^{\mathrm{b}} \pm 0.00$ & $0.00^{\mathrm{c}} \pm 0.00$ & $0.00^{\mathrm{b}} \pm 0.00$ & $0.05^{\mathrm{b}} \pm 0.01$ \\
\hline \multicolumn{5}{c}{ Values are mean \pm standard deviation of 3 replicates } \\
${ }_{\text {abc }}$ Means in a column with different superscripts are significantly different $(P<0.05)$
\end{tabular}

The highest concentration of $\mathrm{Cd}$ in goat blood was obtained in goats at Site $4(0.01 \pm 0.00 \mathrm{mg} / \mathrm{kg})$ and the value is significantly $(p<0.05)$ higher than values obtained at Site $1(0.00 \pm 0.00 \mathrm{mg} / \mathrm{kg})$, Site 2 $(0.00 \pm 0.00 \mathrm{mg} / \mathrm{kg})$, Site $3(0.00 \pm 0.00 \mathrm{mg} / \mathrm{kg})$ and control $(0.00 \pm 0.00 \mathrm{mg} / \mathrm{kg})$. The values of Cd in goat blood increased from 0.00 to $0.01 \mathrm{mg} / \mathrm{kg}$ which is lower than $0.2433 \pm 0.1589$ to $0.2835 \pm 0.1446 \mathrm{mg} / \mathrm{kg}$ (Orisakwe et al., 2017), $0.03 \mathrm{mg} / \mathrm{l}$ (Jubril et al., 2017) and $0.021 \mathrm{mg} / \mathrm{l}$ (Skalicka et al., 2002) but higher than $0.002 \mathrm{mg} / \mathrm{l}$ in goat blood (Or et al., 2005) and $0.006 \pm 0.004 \mathrm{mg} / \mathrm{l}$ in goat blood (Omoniwa et al., 2017). Cadmium is of no biological importance to human/animal growth and development. Cadmium causes reductions in both intestinal zinc absorption and hepatic zinc reserves in cattle, respectively, as a result of competition for the cation-binding sites of metallothionein (Orisakwe et al., 2017). Exposure to cadmium also affect the function of the nervous system (Vaziri, 2008; Lee et al., 2018), with symptoms including headache and vertigo, olfactory dysfunction, Parkinsonian-like symptoms, slowing of vasomotor functioning, peripheral neuropathy, decreased equilibrium, decreased ability to concentrate, and learning disabilities (Abdullahi, 2013). The risk of livestock getting contaminated with heavy metals is a subject of great concern for both food safety and human health because of the toxic nature of metals at relatively minute concentrations (Santhi et al., 2008).

The concentrations of Ni in goat blood were statistically $(p>0.05)$ the same in goats sampled from site $1(0.10 \pm 0.01 \mathrm{mg} / \mathrm{kg})$, Site $2(0.10 \pm 0.02 \mathrm{mg} / \mathrm{kg})$, Site $3(0.10 \pm 0.01 \mathrm{mg} / \mathrm{kg})$ and Site $4(0.12 \pm 0.01$ $\mathrm{mg} / \mathrm{kg}$ ) but the values are significantly $(p<0.05)$ higher than the value of $\mathrm{Ni}$ at the control $(0.05 \pm 0.01$ $\mathrm{mg} / \mathrm{kg}$ ). The values of $\mathrm{Ni}$ increased from 0.05 to $0.12 \mathrm{mg} / \mathrm{kg}$ which is lower than $0.25 \mathrm{mg} / \mathrm{l}$ in goat blood (Yazar et al., 2006) and $1.7869 \pm 1.6479$ to $3.9583 \pm 3.0875 \mathrm{mg} / \mathrm{kg}$ in goat blood (Orisakwe et al., 2017) but higher than $0.03 \mathrm{mg} / \mathrm{l}$ (Miranda et al., 2005) and $0.05 \mathrm{mg} / \mathrm{l}$ (Bernard, 2008). Nickel (Ni) is needed at trace level for normal functioning of the goats. In animals, its deficiency result in depress growth, alterations in carbohydrate and lipid metabolism, delay gestation period, fewer offspring, anaemia, skin eruptions, reduce haemoglobin and hematocrit values, hematopoiesis and alterations in the content of iron, copper, and zinc in liver and reduce activity of several enzymes like hydrogenases, transaminases and $\alpha$-amylase (Alexandrovn et al., 2006; Samal and Mishra, 2011). Notwithstanding this, the lung has been identified as the critical target of nickel toxicity. Nickel substitution for other essential elements may contribute to the adverse health effects of nickel (Al-Ghafari, 2019). The replacement of nickel for magnesium leads to a 40-fold increase in the formation of $\mathrm{C} 3 \mathrm{~b}, \mathrm{Bb}$ enzyme, which amplifies activation of the complement pathway (Orisakwe et al., 2017). The order of abundance of the four heavy metals tested in goat blood in this study is as follows: $\mathrm{Ni}>\mathrm{Cr}>\mathrm{Pb}>\mathrm{Cd}$.

The concentrations of heavy metals on fur of goat are presented in Table 2. The results indicate higher concentrations of metals on goats fur at ex situ than that of in situ. The highest concentration of $\mathrm{Pb}$ $(0.03 \pm 0.01 \mathrm{mg} / \mathrm{kg})$ on goat fur was obtained at Site 1 and the value is significantly $(p<0.05)$ higher than values of $\mathrm{Pb}$ on goat fur at Site $2(0.02 \pm 0.00 \mathrm{mg} / \mathrm{kg})$, Site $3(0.02 \pm 0.00 \mathrm{mg} / \mathrm{kg})$, Site $4(0.02 \pm 0.00$ $\mathrm{mg} / \mathrm{kg}$ ) and control $(0.00 \pm 0.00 \mathrm{mg} / \mathrm{kg})$. The high value of $\mathrm{Pb}$ in goat fur at Site 1 may be as a result of high atmospheric deposition of contaminant (metals) on soil at Site 1 than other sites. The exposure of domestic goats via body contact with (contaminated) soil can be an important route of heavy metal entry (Sabir et al., 2003). The concentration of $\mathrm{Pb}$ in goat fur increased from 0.02 to $0.03 \mathrm{mg} / \mathrm{kg}$ which is lower than 3.76 \pm 0.21 reported in sheep wool at China (Shen et al., 2019), $0.543 \pm 0.062$ to $0.649 \pm 0.048 \mathrm{mg} / \mathrm{kg}$ in fox hair at Poland (Filistowicz et al., 2012) and $2.71 \pm 0.33 \mathrm{mg} / \mathrm{kg}$ in human hair at China (Shen et al., 2019) but higher than $0.35 \pm 0.09$ to $12.0 \pm 0.97 \mu \mathrm{g} / \mathrm{g}$ in goat at Egypt (Rasheed and Soltan, 2005). 
The concentration of $\mathrm{Cr}$ in goat fur was highest in goats sampled at Site $4(0.006 \pm 0.002 \mathrm{mg} / \mathrm{kg})$ and the value is statistically the same $(p>0.05)$ with the concentrations of $\mathrm{Pb}$ in goat fur at Site 1 but significantly $(p<0.05)$ higher than values of $\mathrm{Cr}$ in goat fur at Site $2(0.001 \pm 0.001 \mathrm{mg} / \mathrm{kg})$, Site 3 $(0.001 \pm 0.001 \mathrm{mg} / \mathrm{kg})$ and control $(0.001 \pm 0.001 \mathrm{mg} / \mathrm{kg})$. The concentration of $\mathrm{Cr}$ in goat fur increased from 0.001 to $0.006 \mathrm{mg} / \mathrm{kg}$ which is relatively higher than $0.04 \mathrm{mg} / \mathrm{l}$ reported by Ubwa et al. (2017). The concentration of $\mathrm{Cd}$ in goat fur are statistically equal $(p>0.05)$ for all the sites $(0.00 \pm 0.00$ $\mathrm{mg} / \mathrm{kg}$ ). The values indicated that the level of $\mathrm{Cd}$ at the various sites were very low (Tables 1 and 2 ). The concentration of $\mathrm{Cd}$ on goat fur in this study is lower than $2.28 \pm 0.13 \mathrm{mg} / \mathrm{kg}$ in sheep wool at Egypt (Shen et al., 2019) and 1.88 \pm 0.12 in human hair at China (Shen et al., 2019).

Table 2: Heavy metals on fur of domestic goat

\begin{tabular}{lcccc}
\hline Samples & $\mathrm{Pb}$ & $\mathrm{Cr}$ & $\mathrm{Cd}$ & $\mathrm{Ni}$ \\
\hline Site 1 & $0.03^{\mathrm{a}} \pm 0.01$ & $0.004^{\mathrm{ab}} \pm 0.004$ & $0.00^{\mathrm{a}} \pm 0.00$ & $0.04^{\mathrm{ab}} \pm 0.01$ \\
Site 2 & $0.02^{\mathrm{b}} \pm 0.00$ & $0.001^{\mathrm{b}} \pm 0.001$ & $0.00^{\mathrm{a}} \pm 0.00$ & $0.05^{\mathrm{a}} \pm 0.03$ \\
Site 3 & $0.02^{\mathrm{b}} \pm 0.00$ & $0.001^{\mathrm{b}} \pm 0.001$ & $0.00^{\mathrm{a}} \pm 0.00$ & $0.05^{\mathrm{a}} \pm 0.02$ \\
Site 4 & $0.02^{\mathrm{b}} \pm 0.00$ & $0.006^{\mathrm{a}} \pm 0.002$ & $0.00^{\mathrm{a}} \pm 0.00$ & $0.05^{\mathrm{a}} \pm 0.01$ \\
Control & $0.00^{\mathrm{c}} \pm 0.00$ & $0.001^{\mathrm{b}} \pm 0.001$ & $0.00^{\mathrm{a}} \pm 0.00$ & $0.02^{\mathrm{b}} \pm 0.00$ \\
\hline \multicolumn{5}{c}{ Values are mean \pm standard deviation of 3 replicates } \\
Means in a column with different superscripts are significantly different $(P<0.05)$
\end{tabular}

The concentration of $\mathrm{Ni}$ in goat fur was highest in goats sampled from Site $2(0.05 \pm 0.03 \mathrm{mg} / \mathrm{kg})$, Site $3(0.05 \pm 0.02 \mathrm{mg} / \mathrm{kg})$, Site $4(0.05 \pm 0.01 \mathrm{mg} / \mathrm{kg})$ and Site $1(0.04 \pm 0.01 \mathrm{mg} / \mathrm{kg})$ but the values are significantly $(p<0.05)$ higher than the value observed at the control $(0.02 \pm 0.00 \mathrm{mg} / \mathrm{kg})$. The concentration of $\mathrm{Ni}$ in this study is lower than $0.410 \pm 0.264$ to $0.560 \pm 0.362 \mathrm{mg} / \mathrm{kg}$ in fox hair in Poland (Filistowicz et al., 2012) but higher than $0.71 \pm 0.21$ to $2.11 \pm 0.98 \mu \mathrm{g} / \mathrm{g}$ in goat hair at Egypt (Rasheed and Soltan, 2005). The order of abundance of the four (4) heavy metals tested in this study that may be causing contamination of fur on goats reared ex situ are as follows: $\mathrm{Ni}>\mathrm{Cr}>\mathrm{Pb}>\mathrm{Cd}$.

Comparatively, the values of heavy metals tested in this study were higher in blood than on fur of the goats at various sites. For instance, the concentrations of $\mathrm{Pb}, \mathrm{Cr}, \mathrm{Cd}$ and $\mathrm{Ni}$ were significantly $(p<$ 0.05) higher in the blood than on the fur of the goats (Figure 1 to 4). Consequently, the use of such contaminated blood for formation of blood meal for chicken will lead to bio-magnification of these metals vis-à-vis serious health risk to man. Similarly, the consumption of metal-contaminated goat meat will be a route of entry of heavy metals in human alimentary system. The contribution of livestock to food supplies in developing countries is increasing at a higher rate than that of cereals (FAO, 1994).

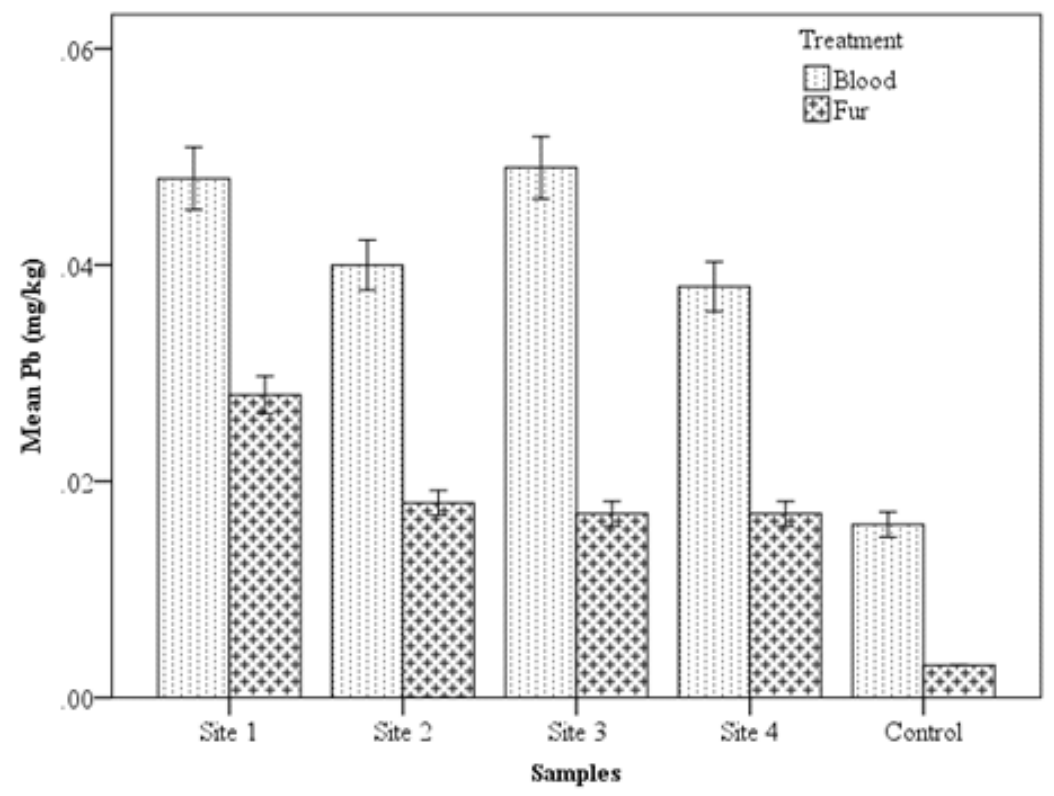

Figure 1: Mean concentration of $\mathrm{Pb}$ in blood and fur 


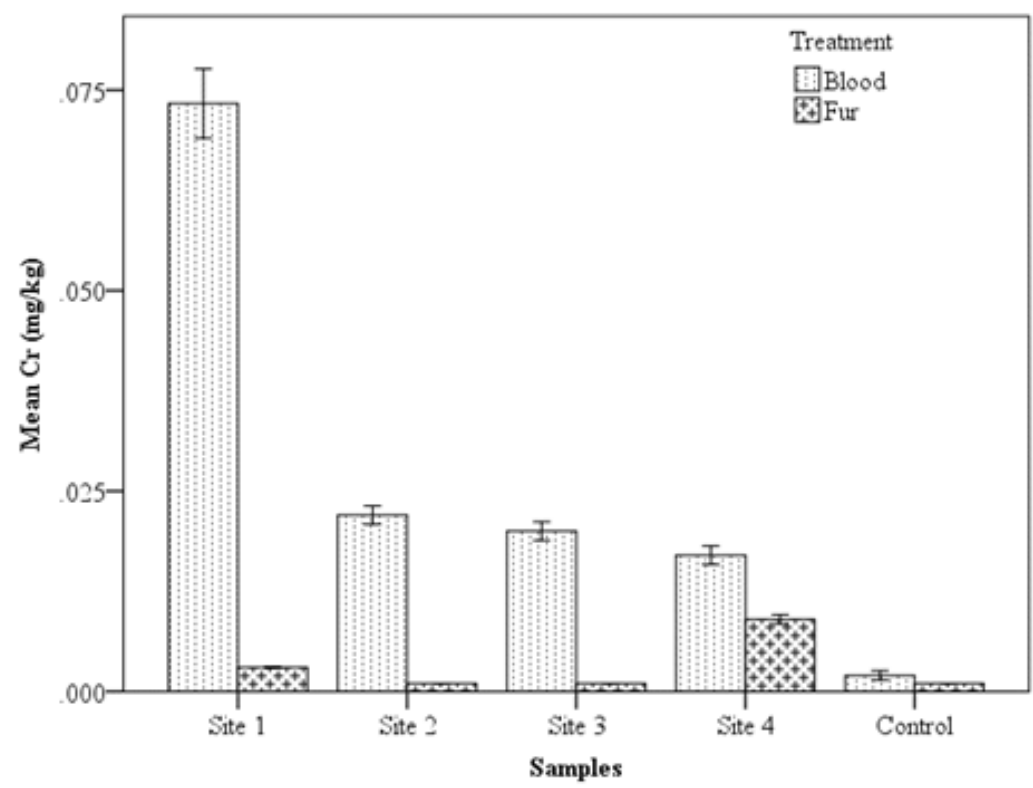

Figure 2: Mean concentration of $\mathrm{Cr}$ in blood and fur

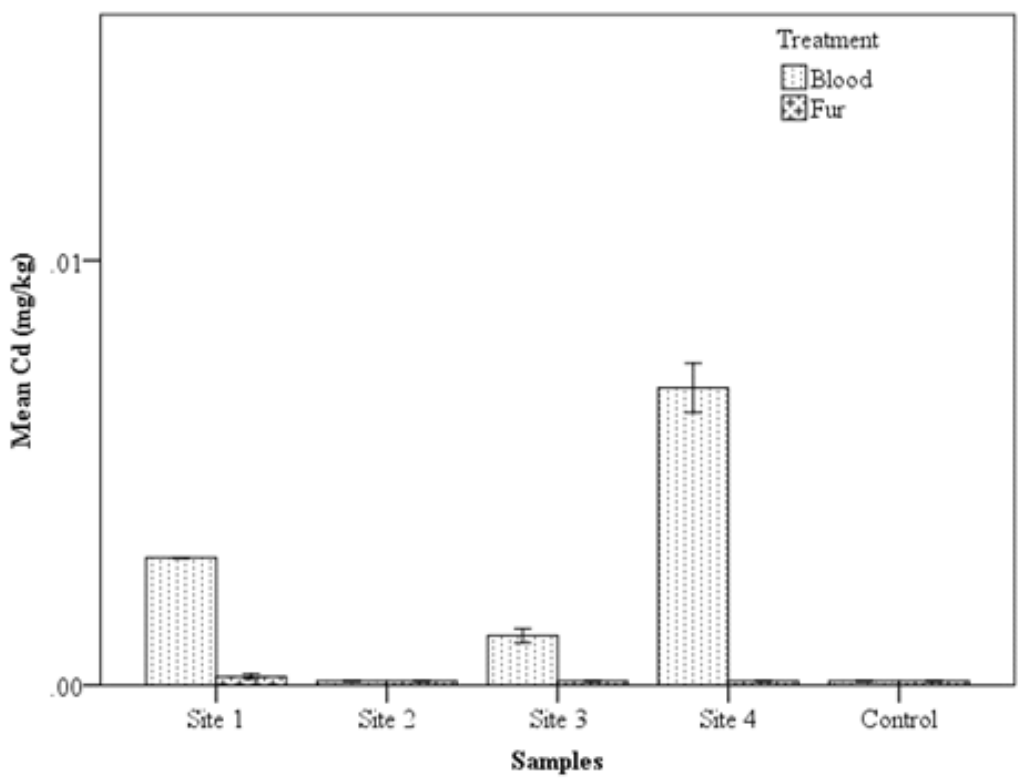

Figure 3: Mean concentration of $\mathrm{Cd}$ in blood and fur

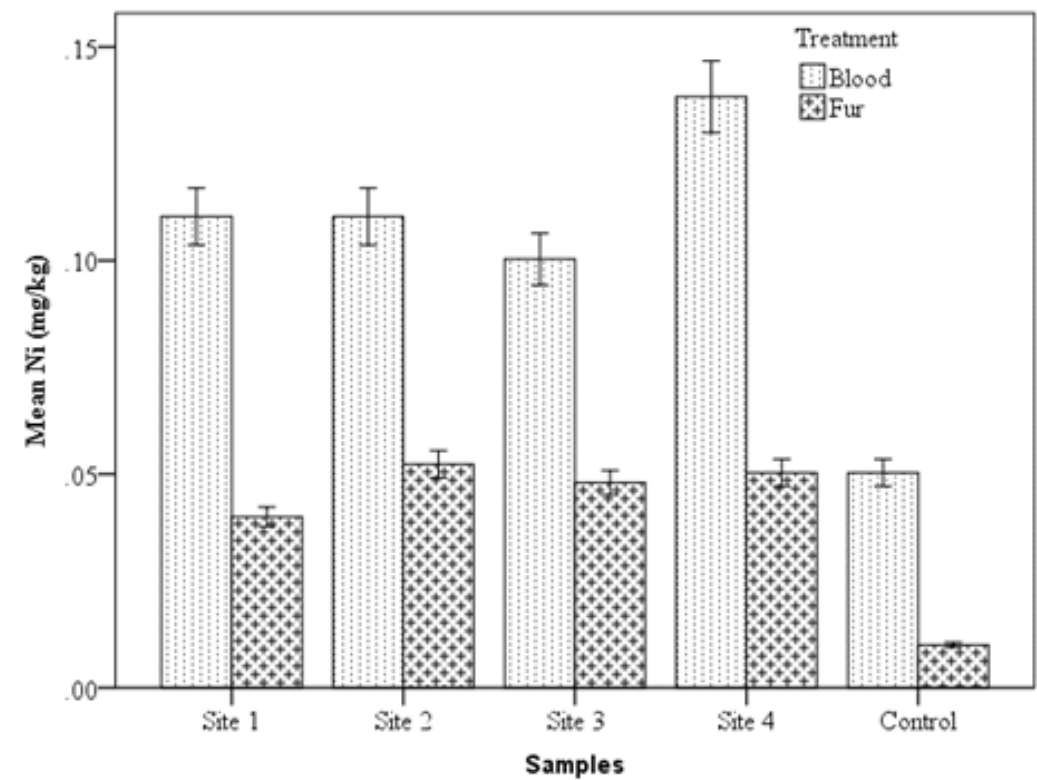

Figure 4: Mean concentration of $\mathrm{Ni}$ in blood and fur 


\subsection{Pearson correlation coefficient of heavy metals in goat blood and fur}

The result of the Pearson correlation analysis of heavy metals in goat blood and fur is summarized in Table 3. The result show very strong positive relationship between heavy metals in blood and fur. For instance, very strong positive relationship exists between $\mathrm{Pb}$ in blood and $\mathrm{Pb}$ in fur $(r=0.855, p<$ $0.01)$ and $\mathrm{Ni}$ in blood and $\mathrm{Ni}$ in fur $(r=0.811, p<0.01)$ which suggest that increase in $\mathrm{Pb}$ and $\mathrm{Ni}$ in blood might have resulted to their $(\mathrm{Pb}$ and $\mathrm{Ni}$ ) increase in goat fur. Strong positive relationship exist between $\mathrm{Pb}$ in blood and $\mathrm{Ni}$ in fur $(r=0.585, p<0.05)$. Positive relationship exist between $\mathrm{Cr}$ in blood and $\mathrm{Cr}$ in fur $(r=0.336)$ and $\mathrm{Cd}$ in blood and $\mathrm{Cd}$ in fur $(r=0.017)$. However, there were very strong positive relationship between $\mathrm{Cr}$ in blood with $\mathrm{Pb}$ in fur $(r=0.685, p<0.01)$, Ni in blood with $\mathrm{Pb}$ in fur $(r=0.651, p<0.01)$ and $\mathrm{Cd}$ in blood with $\mathrm{Cr}$ in fur $(r=0.756, p<0.01)$ while negative relationship occurred between $\mathrm{Cr}$ in blood with $\mathrm{Cd}$ in fur $(r=-0.017), \mathrm{Cr}$ in fur with $\mathrm{Cd}$ in fur $(r=-$ $0.175)$ and $\mathrm{Cd}$ in fur with $\mathrm{Ni}$ in fur $(r=-0.145)$.

Table 3: Correlation between heavy metals in blood and fur

\begin{tabular}{|c|c|c|c|c|c|c|c|c|}
\hline & $\mathrm{Pb}$ (blood) & Cr (blood) & Cd (blood) & $\mathrm{Ni}$ (blood) & $\mathrm{Pb}$ (fur) & $\mathrm{Cr}$ (fur) & Cd (fur) & $\mathrm{Ni}$ (fur) \\
\hline $\mathrm{Pb}$ (blood) & 1 & & & & & & & \\
\hline Cr (blood) & 0.476 & 1 & & & & & & \\
\hline Cd (blood) & 0.155 & -0.017 & 1 & & & & & \\
\hline Ni (blood) & $0.741^{* * *}$ & 0.226 & 0.480 & 1 & & & & \\
\hline $\mathrm{Pb}$ (fur) & $0.855^{* *}$ & $0.685^{* *}$ & 0.066 & $0.651^{\text {** }}$ & 1 & & & \\
\hline $\mathrm{Cr}$ (fur) & 0.167 & 0.336 & $0.756^{* *}$ & 0.439 & 0.188 & 1 & & \\
\hline $\mathrm{Cd}$ (fur) & 0.354 & 0.455 & 0.017 & 0.044 & 0.504 & -0.175 & 1 & \\
\hline $\mathrm{Ni}$ (fur) & $0.585^{*}$ & 0.000 & 0.200 & $0.811^{* * *}$ & 0.413 & 0.150 & -0.145 & 1 \\
\hline
\end{tabular}

\subsection{Conclusion}

The results of the bio-monitoring survey showed that environmental contaminants such as heavy metals contaminated the blood and fur of goats that were fed ex situ than that of in situ. The order of abundance of heavy metals in blood is: $\mathrm{Ni}>\mathrm{Cr}>\mathrm{Pb}>\mathrm{Cd}$ while that of fur is also $\mathrm{Ni}>\mathrm{Cr}>\mathrm{Pb}>\mathrm{Cd}$. The values of highest concentration of heavy metals $(\mathrm{Cr}, \mathrm{Cd}$, and $\mathrm{Pb})$ occurred at Sites 1 and 4 . The level of $\mathrm{Pb}$ and $\mathrm{Cd}$ in goat blood is a serious concern to man and animals' health. Continuous consumption of the goats raised ex situ in Amauzari will likely have adverse effects on the people of Mbano Local Government Area. Thus, we recommend periodic monitoring of environmental contaminants in Amauzari since the goats are being sold to hoteliers, used for preparation of stew and sauce during occasions such as chieftaincy titles, child dedications, new yam festival and burial ceremony. Therefore, it is recommended that rural farmers should be informed about the consequences of raising goats ex situ.

\section{Acknowledgement}

The authors acknowledge the rural goat farmers for given us access to the goats at various sampling sites in this study. The services (statistical analysis of the data) of Mr. Emebu, Prosper Kome are also appreciated.

\section{Conflict of interest}

There is no conflict of interest associated with this work.

\section{References}

Abdullahi, M.S. (2013). Toxic effects of lead in humans: an overview. Global Advanced Journal of Environmental Science and Toxicology, 2(6), pp. 157-162.

Alexandrovn, R., Costisor, O. and Patron, I. (2006). Nickel. Experimental Pathology and Parasitology, 911, pp. 64-74.

Al-Ghafari, A., Elmorsy, E., Fikry, E., Alrowaili, M. and Carter, W.G. (2019). The heavy metals lead and cadmium are cytotoxic to human bone osteoblasts via induction of redox stress. PLoSONE, 14(11), pp. 1-18. 
Assi, M.A., Hezmee, M.N.M., Haron, A.W., Sabri, M.Y. and Rajion, M.A. (2016). The detrimental effects of lead on human and animal health. Veterinary World, 9(6), pp. 660-671.

Bazargani-Gilani, B., Pajohi-Alamoti, M., Bahari, A. and Sari, A.A. (2016). Heavy metals and trace elements in the livers and kidneys of slaughtered cattle, sheep and goats. Iranian Journal of Toxicology, 10(6), pp. 7-13.

Beaumont, J.J., Sedman, R.M., Reynolds, S.D., Sherman, C.D., Li, L.H., Howd, R.A., et al. (2008). Cancer mortality in a Chinese population exposed to hexavalent chromium in drinking water. Epidemiology, 19(1), pp. 12- 23.

Bernard, A. (2008). Heavy metal and their adverse effects on human health. Indian Journal of Medical Research, 128(5), pp. 557-564.

Berny, P.J., Cote, L.M. and Buck, W.B. (1995). Can household pets be used as reliable monitors of lead exposure to humans? Science of the Total. Environment, 172(2-3), pp. 163-173.

Bhattacharya, M., Chatterjee, A., Kishore, R., Sudarsham, M. and Chakraborty, A. (2004). Elemental concentration in hair of domestic animals-a SEM-EDS study. Indian Journal of Veterinary Anatomy, 9, pp. 61-68.

Chadi, A.S. and Abdulhameed, A. (2018). Assessment of heavy metals contents in goat and sheep organs from Ashaka Cements, Gombe State, Nigeria. Journal of Water Technology and Treatment Methods, 1(4), pp. 117-121.

Chiejina, S.N. and Behnke, J.M. (2011). The unique resistance and resilience of the Nigerian West African Dwarf goat to gastrointestinal nematode infections. Parasites and Vectors, 4(1), pp.

Dietz, M.C., Ihrig, A., Wrazidlo, W., Bader, M., Jansen, O. and Triebig, G. (2001). Results of magnetic resonance imaging in long-term manganese dioxide-exposed workers. Environ. Res. 85(1), pp. 37-40.

Egigba, G.O., Odokuma, E.J., Ikhatua, U.J. and Bamikole, M.A. (2018). Concentration of some heavy metals in the hair, kidney and liver of cattle and goats in the oil and non-oil producing areas of Ondo State, Nigeria. Nigerian Journal of Animal Production, 44(3), pp. 49-55.

FAO/WHO (1985). Energy and Protein Requirements. Technical Report. Series 724 World Health Organization, Geneva.

Food and Agriculture Organization, FAO (1990). Manual on simple methods of meat preservation. Health Paper No. 79. FAO, Rome.

Food and Agriculture Organization, FAO (1994). Special Programme on food production for food security in low-income food deficit countries (LIFDCs), Rome.

Flora, G., Gupta, D. and Tiwari, A. (2012) Toxicity of lead: A review with recent updates. Interdisciplinary Toxicology, 5(2), pp. 47-58.

Filistowicz, A., Przysiecki, P., Nowicki, S., Filistowicz, A. and Durkalec, M. (2012). Contents of copper, chromium, nickel, lead and zinc in hair and skin of farm foxes. Polish Journal of Environmental Studies, 21(4), pp. 865-869.

ILCA, (1987). Annual Report of the International Livestock Centre for Africa, ILCA. 1987, Addis Ababa, Ethiopia.

Jabbar, M.A. (1998). Buyer preferences for sheep and goat in southern Nigeria: A hedonic price analysis. Agricultural Economics. 1998, 18: 21-30. 
Järup, L. (2003). Hazards of heavy metal contamination. British Medical Bulletin, 68(1), pp. 167-182.

Keay, R.W.J. (1959). An outlines of Nigeria vegetation. 3rd ed. Government Printer, Lagos, Nigeria.

Jubril, A.J., Taiwo, V.O., Olopade, J.O. and Kabiru, M. (2017). Biological monitoring of heavy metals in goats exposed to environmental; contamination in Bagega, Zamfara State, Nigeria. Advances in Environmental Biology, 11(6), pp. 11-18.

Lee, M.J., Chou, M.C., Chou, W.J., Huang, C.W., Kuo, H.C., Lee, S.Y., et al. (2018). Heavy metals' effect on susceptibility to attention-deficit/hyperactivity disorder: implication of lead, cadmium, and antimony. International Journal of Environmental Research and Public Health, 15, pp. 1221-1232.

Licata, P., Trombetta, D., Cristani, M., Giofre, F., Martino, D., Calo M. and Naccari, F. (2004). Levels of "toxic" and "essential" metals in samples of meat and blood from various farm animals in Calabria, Italy. Journal of Environment International, 30 (1), pp. 1-6.

Manson, P. and Zlotkin, S. (1985). Hair analysis-a critical review. Canadian Medical Association Journal, 133, pp. 186-188.

McCluggage. D. (1991). Heavy metals poisoning, NCS Magazine. The Bird hospital Co.USA www.cockatiels.org/ariticle/diseases/metals.html.

Miranda, M., Lopez-Alonso, M., Castillo, C., Hernadez, J. and Benedito, J.L. (2005). Effects of moderate pollution on toxic and trace metal levels in calves from a polluted area in northern Spain. Environmental International, 31, pp. 543-548.

Mora, M.A., Laack, L.L., Lee, M.C., Sericano, J., Presly, R., Gardinali, P.R. and Gamble, L.R. (2000). Environmental contamination in blood, hair and tissues of Ocelots from the Lower Rio Grande Valley, Texas, 1986-1997. Environ. Monit. Assess. 64(2), pp. 477-492.

Navas-Acien, A., Guallar, E., Silbergeld, E.K. and Rothenberg, S.J. (2007). Lead exposure and cardiovascular disease - A systematic review. Environmental Health Perspectives, 115(3), pp. 472482.

National Population Commission of Nigeria (NPC) (2006). Population and Housing Census Result. NPC, Lagos, Nigeria.

NTP (2008). Technical Report on the toxicology and carcinogenesis studies of sodium dichromate dihydrate (CAS No. 7789-12-0) in F344/N rats and B6C3F1 mice (drinking water studies) National Toxicology Program NIH Publication; 08-5587.

Ogbonna, P.C., Nzegbule, E.C. and Okorie, P.E. (2018). Soil chemical characteristics in wet and dry season at Iva long wall underground mined site, Nigeria. Nigerian Journal of Environmental Sciences and Technology, 2(1), pp. 96-107.

Okiei, W., Ogunlesi, M., Alabi, F., Osiughwu, B and Sojinrin, A. (2009). Determination of toxic metal concentrations in flame treated meat products, Ponmo. African Journal of Biochemistry Research, 3(10), pp. 332-339.

Oladipo, T.A. and Okareh, O.T. (2015). Heavy metals in selected tissues and organs of slaughtered goats from Akinyele Central Abattoir, Ibadan, Nigeria. Journal of Biology, Agriculture and Healthcare, 5(2), pp. 25-29.

Oluokun, J.A., Fajimi, A.K., Adebayo, A.O. and Ajayi, F.T. (2007). Lead and cadmium poisoning of goals raised in cement kiln dust polluted area. Journal Food Agricultural Environment, 1, pp. 382384. 
Omoniwa, O.D., Uchendu, C., Abdullahi, S.U., Bale, J.O.O. and Abdullahi, U.S. (2017). Survey of trace elements and some heavy metals in goats in Zaria and its environs, Kaduna State. Nigerian Veterinary Journal, 38(4), pp. 280-287.

Or, M.E., Kayar, A., Kizilier, A.R., Parkan, C., Gonal, R., Barutai, B. et al. (2005). Determination of levels of some essential and toxic metals in the blood as sheep and samples of water plants and soil in North Western Turkey. Veterinarski Arhive, 19(6), pp. 453 - 456.

Orisakwe, O.E., Oladipo, O.O., Ajaezi, G.C. and Udowelle, N.A. (2017). Horizontal and vertical distribution of heavy metals in farm produce and livestock around lead-contaminated goldmine in Dareta and Abare, Zamfara State, Northern Nigeria. Journal of Environmental and Public Health, 2017, pp. 1-12.

Peacock, C. (2005). Goats - a pathway out of poverty. Small Ruminant Research, 60, pp. 179-186.

Pechova, A. and Pavlata, L. (2007). Chromium as an essential nutrient: a review. Veterinarni Medicine, 1, pp. 1-18.

Rasheed, M.N. and Soltan, M.E. (2005). Animal hair as biological indicator for heavy metal pollution in urban and rural areas. Environmental Monitoring and Assessment, 110, pp.41-53.

Rozso, K., Varhegyi, J., Mocsenyi, A.R. and Fugli, K. (2003). Lead content of the forages and the effect of lead exposure on ruminants. Veterinary Bulletin, 73, pp. 510-510.

Sabir, S.M., Khan, S.W. and Hayat, I. (2003). Effect of environmental pollution on quality of meat in District Bagh, Azad Kashmir. Pakistan Journal of Nutrition, 2(2), 98-101.

Samal, L. and Mishra, C. (2011). Significance of nickel in livestock health and production. International Journal for Agro Veterinary and Medical Sciences, 5(3), pp. 349-361.

Santamaria, A.B. (2008). Manganese exposure, essentiality and toxicity. Indian Journal of Medical Research, 128, pp. 484-500.

Santhi, D., Balakrishnan, V., Kalaikannan, A., and Radhakrishnan, K.T. (2008). Presence of heavy metals in pork products in Chennai (India). American Journal of Food Technology, 3(3), pp. 192-199.

Shekhawat, K., Chatterjee, S. and Joshi, B. (2015). Chromium toxicity and its health hazards. International Journal of Advanced Research, 3(7), pp. 167-172.

Shen, X., Chi, Y. and Xiong, K. (2019). The effect of heavy metal contamination on humans and animals in the vicinity of a zinc smelting facility. PLoS ONE, 14(10), pp. 1-15.

Skalická, M., Koréneková, B., Nad, P. and Makoóvá, Z. (2002). Cadmium levels in pig meat. Veterinarski Archive, 72(1), pp. 11-17.

Steel, R.G.D. and Torrie, J.H. (1980). Principles and procedures of statistics: A biometric approach, McGraw-Hill, New York, p. 633.

Swarup, D., Patra, R.C., Naresh, R., Kumar, P., Shekhar, P. and Balgangadharthilaghar, M. (2006). Lowered blood copper and cobalt contents in goats reared around lead zinc smelter. Small Ruminant Research, 63, pp. 309-313.

Ubwa, S.T., Ejiga, R., Okoye, P.A.C. and Amua, Q.M. (2017).Assessment of heavy metals in the blood and some selected entrails of cows, goat and pigs slaughtered at Wurukun abattoir, Makurdi, Nigeria. Advances in Analytical Chemistry, 7(1), pp. 7-12.

Vaziri, N.D. (2008). Mechanisms of lead-induced hypertension and cardiovascular disease. American Journal of Physiology-Heart and Circulatory Physiology, 295, pp. 454-465. 
Warris, P.D. (2013) Plant species colonizing abandoned farmlands less than 20 years in Isiala Mbano Local Government Area, Imo State, Nigeria. ARPN Journal of Agriculture and Biological Science, 7(2):117-120.

Wilson, T. (2011). Small ruminant production and the small ruminant genetic resource in tropical Africa. Rome: Food and Agriculture Organization (FAO) of the United Nations, (FAO Animal Production and Health Paper 88), 231 pp.

Yazar, E., Altunok, V. and Erogulu, T. (2006): Concentrations of some elements in the blood serums of Angora goats. Medycena Weterynaryjna, 11, pp. 1249-1251.

\section{Cite this article as:}

Ogbonna P. C., Dikeogu, E. C., Nwankwo, O. U., Kanu, K. C. and Osuagwu E. C. 2021. Bio-monitoring of environmental toxicants using West African dwarf goats at Amawzari Mbano, Imo State, Nigeria. Nigerian Journal of Environmental Sciences and Technology, 5(1), pp. 258-270. https://doi.org/10.36263/nijest.2021.01.0279 